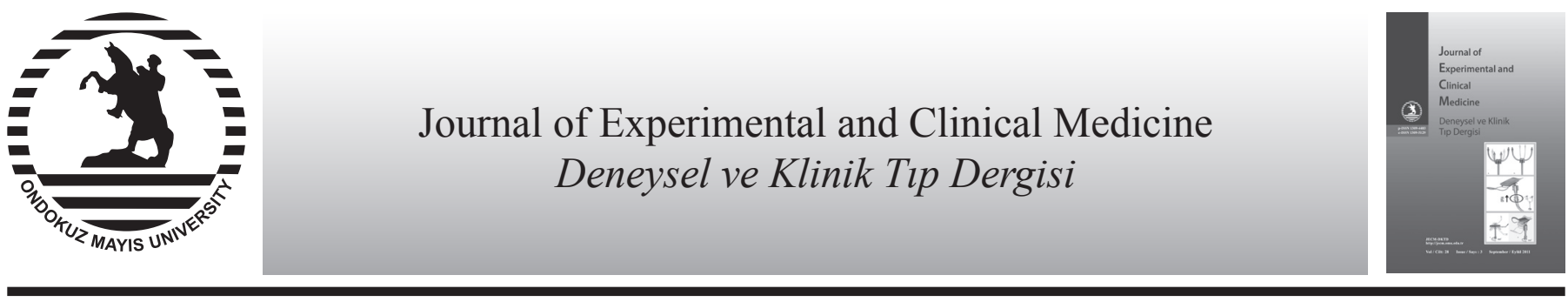

Experimental Research

doi: $10.5835 /$ jecm.omu.28.03.002

\title{
Immunohistochemical investigation of caspase-3 in neuronal apoptosis after experi- mental closed head trauma
}

\author{
Cevat Aktaş ${ }^{a^{*}}$, Mehmet Kanter ${ }^{\mathrm{b}}$, Duygu Uzun ${ }^{\mathrm{b}}$, Zeynep Fidanol ${ }^{\mathrm{b}}$ \\ ${ }^{a}$ Department of Histology and Embryology, Faculty of Medicine, Namik Kemal University, Tekirdag, Turkey \\ ${ }^{b}$ Department of Histology and Embryology, Faculty of Medicine, University of Trakya, Edirne, Turkey
}

\begin{tabular}{ll}
\hline ARTICLE INFO & ABSTRACT \\
\hline $\begin{array}{l}\text { Article History } \\
\text { Received } 21 / 06 / 2011\end{array} \quad \begin{array}{l}\text { The aim of this study was to investigate the caspase-3 activity in neuronal apoptosis after } \\
\text { experimental closed head trauma model in rats. Twenty adult male rats were randomly } \\
\text { divided into two groups: control and trauma groups. In trauma group, a cranial impact } \\
\text { was delivered to the skull from a height of } 7 \mathrm{~cm} \text { at a point just in front of the coronal } \\
\text { suture and over the right hemisphere. Rats were sacrificed at } 12 \text { hours after the onset } \\
\text { of injury. Brain tissues were removed for histopathological investigation. In the trauma } \\
\text { group, the neurons became extensively dark and degenerated into picnotic nuclei. The } \\
\text { * Correspondence to }\end{array}$ & $\begin{array}{l}\text { number of apoptotic neurons in frontal cortex tissue of trauma group was significantly } \\
\text { more than control groups. In conclusion, the caspase } 3 \text { immunopositivity was increased } \\
\text { Cevat Aktaş }\end{array}$ \\
$\begin{array}{l}\text { in degenerating neurons of the frontal cortex tissue following trauma. The present results } \\
\text { indicate that closed head trauma caused degenerative changes and increased caspase } 3\end{array}$ \\
$\begin{array}{l}\text { Faculty of Medicine, } \\
\text { immomik Kemal University, } \\
\text { Tekirdag, Turkey }\end{array}$ J. Exp. Clin. Med., 2011; 99-102 \\
e-mail: cevata@yahoo.com
\end{tabular}

Keywords:

Closed head trauma

Brain tissue

Immunohistochemistry

Caspase-3

Apoptosis

Rat

(C) 2011 OMU All rights reserved

\section{Introduction}

In humans, frontal impact, closed head trauma is arguably the most frequently encountered cause of traumatic brain injury, especially with motor vehicle, sports, and other types of accidents, and accounts for a disproportionate number of diffuse brain injuries (Adams et al., 1982; Adams et al., 1989; Cecil et al., 1998). Diffuse brain injury is often marked by subarachnoid hemorrhage, scattered intraparenchymal petechial hemorrhages, and diffuse axonal injury. Diffuse axonal injury is a common primary lesion both in humans and in experimental animals, and results from shearing forces that develop within the anisotropic brain, especially when it is subjected to rotational acceleration (Gennarelli et al., 1981; Gennarelli et al., 1982; Prange et al., 2000).

Apoptosis, a type of programmed cell death, is a major event in normal development of the nervous system, playing an important role in the establishment of neuronal connections (Oppenheim, 1991; Oppenheim, 1996; Clarke et al., 1998). Apoptotic cell death is executed via molecular pathways that are mediated by the activation of caspases, a family of cysteine proteases (Zimmermann et al., 2001). Caspase-3, a main effector caspase, is strongly implicated in neuronal apoptosis (Cohen, 1987), which occurs due to competition for, or limited supply of, neurotrophins that suppress the endogenous genetic death program. Evidence suggests that experimental axotomy or target elimination and withdrawal of neurotrophins result in an increase in apoptosis during development and in the adult (Henderson, 1996; Hörtnagl, 1997). In the present study, we aimed to investigate the capase- 3 activity in experimental closed head trauma model in rats.

\section{Materials and methods}

Animals

Twenty healthy male Sprague-Dawley rats averaging 16 weeks old were utilized in this study. The rats were kept in a windowless animal quarter where temperature $\left(22 \pm 2 \mathrm{C}^{\circ}\right)$ and illumination were automatically controlled (light on at 07 am and off at $09 \mathrm{pm}: 14 \mathrm{~h}$ light/10 h dark cycle). Humidity ranged from $50 \%$ to $55 \%$. All animals received human care according to the criteria outlined in the 'Guide for the Care 
and Use of Laboratory Animals' prepared by the National Academy of Sciences and published by the National Institutes of Health. The study was approved by the Institutional Animal Ethical Committee of the Namik Kemal University, Tekirdag, Turkey.

\section{Experimental design}

Animals were divided randomly into two groups: Control and closed head trauma; each group contain 10 animals. Rats were sacrificed at 12 hours after the onset of injury.

\section{Closed head trauma procedure}

Rats were anesthetized with an intraperitoneal injection of ketamine hydrochloride $(70 \mathrm{mg} / \mathrm{kg}$ ) and xylazin hydrochloride $(7 \mathrm{mg} / \mathrm{kg})$. The animals maintained spontaneous breathing. The heads of the animals were fixed into the head injury device with the chin resting firmly on the bottom plane. The application of the closed head injury was made according to the modified method described by Shapira et al. (1988). In trauma group, the cranial impact was induced to a point on the right hemisphere $2 \mathrm{~mm}$ lateral to the midline and just in front of the coronal suture. The free fall occurred from a height of $7 \mathrm{~cm}$, preferable for producing impact energy of 0.5 Joules over the skull. The rats were decapitated 12 hours after the onset of the injury. Frontal brain tissues were removed for histopathological investigation.

\section{Histological Examinations}

Brain tissue were harvested from the sacrificed animals, and the tissues were fixed in 10\% neutral buffered formaline, embedded in paraffin, sectioned at $5 \mu \mathrm{m}$ thickness and then, stained with heamatoxyline and eosine. Histological specimens were examined in light microscopy (Nikon Optiphot II, Japan).

\section{Immunohistochemistry for Caspase-3}

For immunohistochemical observations, the brain tissues were fixed in $10 \%$ neutral buffered formaline, embedded in paraffin and sectioned at $5 \mu \mathrm{m}$ thickness. Immunocytochemical reactions were performed according to the $\mathrm{ABC}$ technique described by Hsu et al., (1981). The procedure involved the following steps: (1) endogenous peroxidase activity was inhibited by $3 \% \mathrm{H}_{2} \mathrm{O}_{2}$ in distilled water for $30 \mathrm{~min}$; (2) the sections were washed in distilled water for $10 \mathrm{~min}$; (3) nonspecific binding of antibodies was blocked by incubation with normal goat serum (DAKO X 0907, Carpinteria, CA) with PBS, diluted $1: 4$; (4) the sections were incubated with specific rabbit polyclonal anti-caspase-3 antibody (Cat. \#RB1197-P, Neomarkers, USA) diluted 1:50 for $1 \mathrm{~h}$ at room temperature; (5) the sections were washed in PBS $3 \times 3 \mathrm{~min}$; (6) the sections were incubated with biotinylated anti-mouse IgG (DAKO LSAB 2 Kit); (7) the sections were washed in PBS 3 $\times 3 \mathrm{~min}$; (8) the sections were incubated with ABC complex (DAKO LSAB 2 Kit); (9) the sections were washed in PBS 3 $\times 3$ min; (10) peroxidase was detected with diaminobenzidine as substrate for $10 \mathrm{~min}$; 11) the sections were washed in PBS; 12) the sections were counterstained with hematoxylin for 1 min, dehydrated through a graded ethanol series; and 13) the sections were mounted in DAKO paramount. As a negative control, primary antibody was replaced with PBS. All dilutions and thorough washes between steps were performed using phosphate buffered saline unless otherwise specified. All steps were carried out at room temperature unless otherwise specified. As a negative control, primary antibody was replaced with PBS.

\section{Microscopic examination}

Histological specimens of the frontal cortex were examined under light microscopy, with the examination carried out at a magnification of 400 and the counts of neurons determined per square millimeter with the use of a standardized ocular grid. Apoptotic neurons (strong caspase 3 immunopositive) were counted. The distribution of neurons was examined in the sections from the specimens were subjected to immunohistochemical staining by using anticaspase- 3 antibody. Tissue sections were examined under light microscopy $(\times 400)$ and the number of the neurons counted within random highpower fields using a Nikon Optiphot 2 light microscope incorporating a square graticule in the eyepiece (eyepiece $\times 10$, objective $\times 40$, a total side length of $0.25 \mu \mathrm{m} 2$ ). Neuron density was assessed by counting the number of cells in 400 high power fields amongst the frontal cortex tissue preparations of each group. The neuron density in each site was calculated and recorded as the number of neurons $/ \mu \mathrm{m} 2$. The tissue compartments were used to record neuron distribution in the frontal cortex tissue.

\section{Statistical Analysis}

All statistical analyses were carried out using SPSS statistical software (SPSS for windows, version 11.0). All data was presented in mean $( \pm$ ) standard deviations (S.D.). Differences in measured parameters among the three groups were analyzed with a Kruskal-Wallis test. Dual comparisons between groups exhibiting significant values were evaluated with a Mann-Whitney U-test. These differences were considered significant when probability was less than 0.05 .

\section{Results}

Histological findings: In the control group, the morphology of neurons in the brain tissue was normal (Fig. 1a). In the
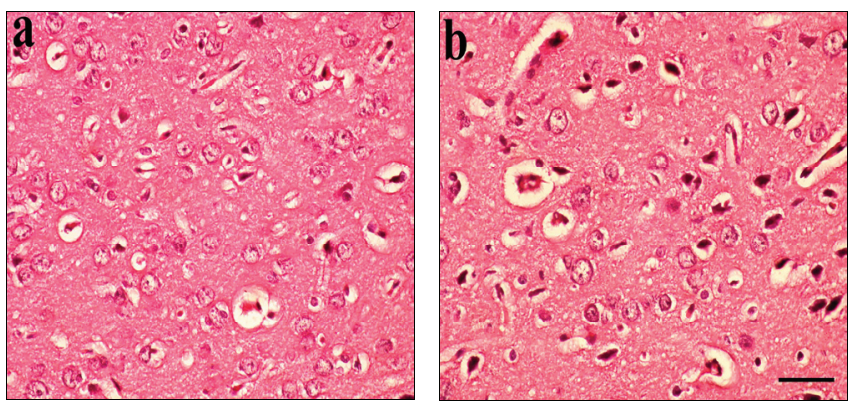

Fig. 1. Representative light microphotographs showing the morphology of the frontal cortex tissue by hematoxylin-eosin. (a) Control group: Normal frontal cortex tissue histology is seen. (b) Closed head trauma group: Severe degenerative changes, shrinkage cytoplasm and extensively dark picnotic nuclei in neurons of the frontal cortex tissue are seen. (H\&E, scale bar, $50 \mu \mathrm{m})$.

closed head trauma group, the most consistent findings occurring in the histological tissue sections stained with hematoxylin-eosin were those indicating severe degenerative changes, shrunken cytoplasma and extensively dark picnotic nuclei in neurons (Fig. 1b).

Immunohistochemical findings

Mild caspase-3 immunoreactivity was observed in the cytoplasm of neurons in control rats (Fig. 2a). The micrographs showed apoptotic neurons by caspase- 3 immunohistochemis- 

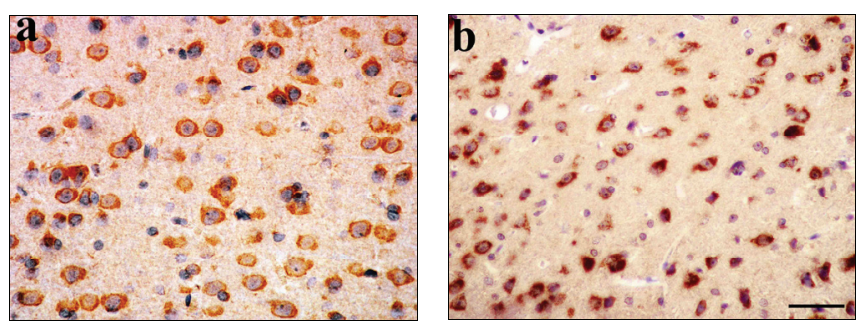

Fig. 2. Representative light microphotographs showing apoptosis of the frontal cortex tissue by caspase- 3 immunohistochemistry. (a) Control group: Neuronal cells are mildly stained with the anti-caspase-3 antibody. (b) Closed head trauma group: The caspase- 3 immunopositivity was strongly increased in degenerating neurons of the frontal cortex tissue after trauma. (Immunoperoxidase, haematoxylin counterstain, scalebar, $50 \mu \mathrm{m})$

try after closed head trauma in rats. The caspase 3 immunopositivity was increased in degenerating neurons of the frontal cortex tissues following closed head trauma (Fig. 2b).

Table 1. The numbers (number/ $\mu \mathrm{m} 2$ ) of apoptotic neurons (strong caspase 3 immunopositive) in the frontal cortex tissues of control and closed head trauma groups.

\begin{tabular}{lc}
\hline Groups & Brain tissue \\
\hline Control & $10.31 \pm 5.72$ \\
Closed head trauma & $79.24 \pm 3.96^{*}$ \\
\hline
\end{tabular}

The data is expressed as mean \pm standard deviation (S.D.), $(\mathrm{n}=10)$. ${ }^{*} \mathrm{P}<0.0001$ when compared to control group.

On the other hand, the number of apoptotic neurons were increased significantly in closed head trauma group compared to control $(\mathrm{P}<0.0001)$, (Table 1).

\section{Discussion}

Trauma to the brain causes tissue damage by primary and secondary injury to the neural tissue. Primary injury, due to an initial mechanical trauma, results in physical disruption of vessels, neurons and their axons (Marshall, 2000; Ozsuer et al., 2005). Secondary Siesjo, (1993) injury, at the subcellular level, follows the primary impact and causes the death of additional tissue at the peripheral zone of the initial damage. Alleviation of this type of injury is considered the main target of medical treatment (Ozsuer et al., 2005). As far as the mechanisms of secondary brain damage are considered, oxygen free radicals and lipid peroxidation are believed to play crucial roles (McCall et al., 1987; Ikeda and Long, 1990; Clausen et al., 2004). Free radicals are important factors in secondary damage after brain trauma (Sochman, 2002 Shen et al., 2003; ). It has been postulated that free radicals are linked to pathophysiological processes, including loss of microvascular autoregulation and hypoperfusion, traumatic subarachnoid hemorrhage induced vasospasm, vasogenic edema, and failure of energy metabolism (Clausen et al., 2004). The secondary injury at the subcellular level that follows the primary impact causes the death of additional tissue at the peripheral zone of the initial damage and is considered to be the main target of medical treatment.

In this study, closed head trauma caused severe degenerative changes, shrunken cytoplasma and extensively dark picnotic nuclei in neurons of the frontal cortex tissues. This observation is in agreement with previous studies, which suggest that closed head trauma caused severe degenerative changes in neurons of frontal cortex and NAC treatment prevented this neuronal damage (Hicdonmez et al., 2006).

In the present study, the caspase 3 immunopositivity was increased in degenerating neurons of the frontal cortex tissues following closed head trauma. Our results are in agreement with reports of other workers, which suggest that closed head trauma caused apotosis in the frontal cortex (Stone et al., 2002; Lau et al., 2006; Dressler et al., 2007; Kilbourne et al., 2009; Kim et al., 2010).

Caspase-3 immunostaining was observed in neurons distributed around the lesioned area at $24 \mathrm{~h}$ after traumatic brain injury and the number of immunopositive neurons increased at 48 and $72 \mathrm{~h}$ post-injury ( $\mathrm{Lu}$ et al., 2003). Cernak et al. (2002) have demonstrated an increased expression of active caspase- 3 protein as early as $24 \mathrm{~h}$ after diffuse injury and persisting for almost 1 week. Moreover, the decrease in procaspase-3 levels suggests a conversion to the active form may have occurred as early as $4 \mathrm{~h}$ after injury. Thus, apoptosis seems activated early after diffuse traumatic brain injury and continues for at least 5 days post-trauma. Caspase-3 activity has been shown to be increased after ischemic insults, as well as following both experimental (Yakovlev et al., 1997; Clark et al., 2000) and clinical traumatic brain injury (Clark et al., 2000). The occurrence of apoptosis in the cortex and the hippocampus following experimental focal brain trauma was correlated with the induction of caspase- 3 mRNA expression which showed significant elevation as early as $4 \mathrm{~h}$ after TBI continuing for at least 3 days posttrauma (Nicholson, 1999). In our study, the caspases-3 immunopositivity was increased in neurons of frontal brain tissue at $12 \mathrm{~h}$ following trauma. In conclusion, the findings obtained in the present study indicate that closed head trauma causes neuronal damage and increase caspase 3 immonupositivity in neurons.

\section{REFERENCES}

Adams, J.H., Doyle, D., Ford, I., Gennarelli, T.A., Graham, D.I., McLellan, D.R., 1989. Diffuse axonal injury in head injury: definition, diagnosis and grading. Histopathology 15, 49-59.

Adams, J.H., Graham, D.I., Murray, L.S., Scott, G., 1982. Diffuse axonal injury due to nonmissile head injury in humans: an analysis of 45 cases. Ann. Neurol. 12, 557-563.

Cecil, K.M., Hills, E.C., Sandel, M.E., Smith, D.H., McIntosh, T.K., Mannon, L.J., Sinson, G.P., Bagley, L.J., Grossman, R.I., Lenkinski, R.E., 1998. Proton magnetic resonance spectroscopy for detection of axonal injury in the splenium of the corpus callosum of brain-injured patients. J. Neurosurg. 88, 795-801.

Cernak, I., Chapman, S.M., Hamlin, G.P., Vink, R., 2002. Temporal characterisation of pro- and anti-apoptotic mechanisms following diffuse 
traumatic brain injury in rats. J. Clin. Neurosci. 9, 565-572.

Clark, R.S., Kochanek, P.M., Watkins, S.C., Chen, M., Dixon, C.E., Seidberg, N.A., Melick, J., Loeffert, J.E., Nathaniel, P.D., Jin, K.L, Graham, S.H., 2000. Caspase-3 mediated neuronal death after traumatic brain injury in rats. J. Neurochem. 74, 740-753.

Clarke, P.G., Posada, A., Primi, M.P., Castagne, V., 1998. Neuronal death in the central nervous system during development. Biomed. Pharmacother. 52, 356-362.

Clausen, F., Lundqvist, H., Ekmark, S., Lewen, A., Ebendal, T., Hillered, L., 2004. Oxygen free radical-dependent activation of extracellular signal-regulated kinase mediates apoptosis-like cell death after traumatic brain injury. J. Neurotrauma. 21, 1168-1182.

Cohen, G.M., 1997. Caspases: the executioners of apoptosis. Biochem. J. 326, 1-16.

Dressler, J., Hanisch, U., Kuhlisch, E., Geiger, K.D., 2007. Neuronal and glial apoptosis in human traumatic brain injury. Int. J. Legal. Med. $121,365-375$.

Gennarelli, T.A., Adams, J.H., Graham, D.I., 1981. Acceleration induced head injury in the monkey. I. The model, its mechanical and physiological correlates. Acta Neuropathol. Suppl. 7, 23-25.

Gennarelli, T.A., Thibault, L., Adams, J.H., Graham, D.I., Thompson, C.J., Marcincin, R.P., 1982. Diffuse axonal injury and traumatic coma in the primate. Ann. Neurol. 12, 564-574.

Henderson, Z., 1996. Responses of basal forebrain cholinergic neurons to damage in the adult brain. Prog. Neurobiol. 48, $219-254$.

Hicdonmez, T., Kanter, M., Tiryaki, M., Parsak, T., Cobanoglu, S., 2006. Neuroprotective effects of n-acetylcysteine on experimental closed head trauma in rats. Neurochem. Res. 31, 473-481.

Hörtnagl, H., Hellweg, R., 1997. Insights into the role of the cholinergic component of the septohippocampal pathway: what have we learned from experimental lesion studies? Brain Res. Bull. 43, 245-255.

Hsu, S.M., Raine, L., Fanger, H., 1981. Use of avidin-biotin-peroxidase complex (ABC) in immunperoxidase techniques: a comparison between $\mathrm{ABC}$ and unlabeled antibody (PAP) procedures. J. Histochem. Cytochem. 29, 577-580.

Ikeda, Y., Long, D.M., 1990. The molecular basis of brain injury and brain edema: the role of oxygen free radicals. Neurosurgery. $27,1-11$.

Kilbourne, M,M., Kuehn, R., Tosun, C., Caridi, J., Keledjian, K., Bochicchio, G., Scalea, T., Gerzanich, V., Simard, J.J., 2009. Novel model of frontal impact closed head injury in the rat. J. Neurotrauma. 26, 2233-2243.

Kim, D.H., Ko, I.G., Kim, B.K., Kim, T.W., Kim, S.E., Shin, M.S., Kim, C.J., Kim, H., Kim, K.M., Baek, S.S., 2010. Treadmill exercise inhibits traumatic brain injury-induced hippocampal apoptosis. Physiol. Behav. 101, 660-665.

Lau, A., Arundine, M., Sun, H.S., Jones, M., Tymianski, M., 2006. Inhibition of caspase-mediated apoptosis by peroxynitrite in traumatic brain injury. J. Neurosci. 26, 11540-11553.

Lu, J., Moochhala, S., Shirhan, M., Teo, A.L., Tan, M.H., Moore, X.L., Wong, M.C., Ling, E.A., 2003. Neuroprotection by aminoguanidine after lateral fluid-percussive brain injury in rats: a combined magnetic resonance imaging, histopathologic and functional study. Neuropharmacol. 44, 253-263.

Marshall, L.F., 2000. Head injury: recent past, present, and future. Neurosurgery. 47, 546-561.

McCall, J.M., Braughler, J.M., Hall, E.D., 1987. Lipide peroxidation and the role of oxygen radicals in CNS injury. Acta. Anaesthesiol. Belg. 38, 373-379.

Nicholson, D.W., 1999. Caspase structure, proteolytic substrates, and function during apoptotic cell death. Cell. Death. Differ. 6, $1028-1042$.

Oppenheim, R.W., 1991. Cell death during development of the nervous system. Annu. Rev. Neurosci. 14, 453-501.

Oppenheim, R.W., 1996. The concept of uptake and retrograde transport of neurotrophic molecules during development: history and present status. Neurochem. Res. 21, 769-777.

Ozsuer, H., Gorgulu, A., Kiris, T., Cobanoglu, S., 2005. The effects of memantine on lipid peroxidation following closed-head trauma in rats. Neurosurg. Rev. 28, 143-147.

Prange, M.T., Meaney, D.F., Margulies, S.S., 2000. Defining brain mechanical properties: effects of region, direction, and species. Stapp. Car. Crash. J. 44, 205-213.

Shapira, Y., Shohami, E., Sidi, S., Soffer, D., Freeman, S., Cotev, S., 1988. Experimental closed head injury in rats: mechanical, pathophysiologic and neurologic properties. Crit. Care. Med. 16, 258-265.

Shen, W.H., Zhang, C.Y., Zhang, G.Y., 2003. Antioxidants attenuate reperfusion injury after global brain ischemia through inhibiting nuclear factor-kappa B activity in rats. Acta Pharmacol. Sin. 24, 1125-1130.

Siesjo, B.K. 1993. Basic mechanisms of traumatic brain damage. Ann. Emerg. Med. 22, 959-969.

Sochman, J., 2002. N-acetylcysteine in acute cardiology: 10 years later: what do we know and what would we like to know. J. Am. Coll. Cardiol. $39,1422-1428$.

Stone, J.R., Okonkwo, D.O., Singleton, R.H., Mutlu, L.K., Helm, G.A., Povlishock, J.T., 2002. Caspase-3-mediated cleavage of amyloid precursor protein and formation of amyloid beta peptide in traumatic axonal injury. J. Neurotrauma. 19, 601-614.

Yakovlev, A.G., Knoblach, S.M., Fan, L., Fox, G.B., Goodnight, R., Faden, A.I., 1997. Activation of CPP32-like caspases contributes to neuronal apoptosis and neurological dysfunction after traumatic brain injury. J. Neurosci. 17, 7415-7424.

Zimmermann, K.C., Bonzon, C., Green, D.R., 2001. The machinery of programmed cell death. Pharmacol. Ther. 92, 57-70. 